\title{
Influence of Drying Temperature on the Structural, Optical, and Electrical Properties of Layer-by-Layer ZnO Nanoparticles Seeded Catalyst
}

\author{
S. S. Shariffudin, ${ }^{1}$ M. H. Mamat, ${ }^{1}$ S. H. Herman, ${ }^{1}$ and M. Rusop ${ }^{1,2}$ \\ ${ }^{1}$ NANO-ElecTronic Centre, Faculty of Electrical Engineering, Universiti Teknologi MARA, Selangor, 40450 Shah Alam, Malaysia \\ ${ }^{2}$ NANO-SciTech Centre, Institute of Science, Universiti Teknologi MARA, Selangor, 40450 Shah Alam, Malaysia
}

Correspondence should be addressed to S. S. Shariffudin, sobihana@gmail.com

Received 24 July 2012; Revised 15 October 2012; Accepted 16 October 2012

Academic Editor: Lian Gao

Copyright () 2012 S. S. Shariffudin et al. This is an open access article distributed under the Creative Commons Attribution License, which permits unrestricted use, distribution, and reproduction in any medium, provided the original work is properly cited.

\begin{abstract}
Layer-by-layer zinc oxide $(\mathrm{ZnO})$ nanoparticles have been prepared using sol-gel spin coating technique. The films were dried at different temperature from $100^{\circ} \mathrm{C}$ to $300^{\circ} \mathrm{C}$ to study its effect to the surface morphology, optical and electrical properties of the films. Film dried at $200^{\circ} \mathrm{C}$ shows the highest $\left(\begin{array}{lll}0 & 0 & 2\end{array}\right)$ peak of X-ray diffraction pattern which is due to complete decomposition of zinc acetate and complete vaporization of the stabilizer and solvent. It was found that the grain size increased with the increased of drying temperature from 100 to $200^{\circ} \mathrm{C}$, but for films dried at above $200^{\circ} \mathrm{C}$, the grain size decreased. Photoluminescence measurements show a sharp ultraviolet emission centred at $380 \mathrm{~nm}$ and a very low intensity visible emission. Blue visible emission was detected for sample dried at temperature below $200^{\circ} \mathrm{C}$, while for films dried above $250^{\circ} \mathrm{C}$, the visible emission is red shifted. The films were transparent in the visible range from 400 to $800 \mathrm{~nm}$ with average transmittance of above $85 \%$. Linear $I$ - $V$ characteristics were shown confirming the ohmic behaviour of the gold contacts to the films. A minimum resistivity was given by $5.08 \Omega \cdot \mathrm{cm}$ for the film dried at $300^{\circ} \mathrm{C}$.
\end{abstract}

\section{Introduction}

Recently, $\mathrm{ZnO}$ is aggressively used in optoelectronic devices such as light emitting diodes and solar cells due to its properties of direct band gap of $3.37 \mathrm{eV}$ and high exciton binding energy of $60 \mathrm{meV}$. Nanorods, nanowires, nanoflowers, nanoparticles, nanowalls, and nanotubes were among the many kinds of $\mathrm{ZnO}$ nanostructures that have been produced by many. In order to grow $\mathrm{ZnO}$ nanorods and nanowires, various methods have been applied such as chemical vapour deposition (CVD) method [1], metal organic CVD (MOCVD) [2], aqueous chemical growth (ACG) method [3], and spray pyrolysis [4].

In the CVD method, vapour-liquid-solid (VLS) mechanism had been applied since quite some time ago, which uses metals such as gold [5] and platinum [6], or transition metal such as nickel [7] as the catalyst to enhance the growth of the $\mathrm{ZnO}$ nanorods. However, due to the impurity of the metal to the $\mathrm{ZnO}$ nanorods, researches started to employ noncatalyst or self-catalysed process, which applied vapour-solid (VS) mechanism as the growth method. According to Cha et al., the growth direction of the $\mathrm{ZnO}$ nanowires depended on the crystal structure of the substrate or seeded catalyst [8]. In order for the $\mathrm{ZnO}$ nanorods to grow vertically aligned with good quality, the $\mathrm{ZnO}$ seeded catalyst needs to be highly

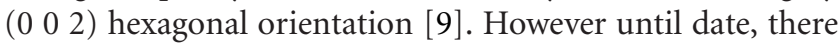
is no report on the growth of $\mathrm{ZnO}$ nanorods using seeded catalyst deposited using sol-gel spin coating technique. Solgel spin coating technique has been widely used to deposit thin films due to its ease of deposition, homogeneity, and low crystallization temperature [10]. Furthermore, many have reported on producing highly c-axis $\mathrm{ZnO}$ thin films using spin coating technique either single crystal $[11,12]$ or polycrystalline $[10,13,14]$. Therefore the aim of our study is to deposit $\mathrm{ZnO}$ nanoparticles using spin coating technique with high c-axis orientation to be used as seeded catalyst for the growth of $\mathrm{ZnO}$ nanorods by CVD method. 
In the present work, we studied the physical properties, photoluminescence spectra, transmittance spectra, and current-voltage $(I-V)$ characteristics of the sol-gel spin coated $\mathrm{ZnO}$ thin films in order to investigate the optimum properties of the $\mathrm{ZnO}$ nanoparticles to be used as seeded catalyst.

\section{Experimental Procedure}

Zinc acetate dihydrate $\left(\mathrm{Zn}\left(\mathrm{CH}_{3} \mathrm{COO}\right)_{2} \cdot 2 \mathrm{H}_{2} \mathrm{O}, 99 \%\right.$; SigmaAldrich) was dissolved in 2-methoxyethanol $\left(\mathrm{C}_{3} \mathrm{H}_{8} \mathrm{O}_{2}, 99 \%\right.$; Sigma-Aldrich) with addition of monoethanolamine (MEA: $\mathrm{H}_{2} \mathrm{NCH}_{2} \mathrm{CH}_{2} \mathrm{OH}$, 99.5\%; Merck) as the stabilizer. The concentration of zinc acetate was $0.4 \mathrm{~mol} / \mathrm{L}$ while the molar ratio of MEA to zinc acetate was kept at 1.0. The solution was stirred on a hot plat stirrer with applied temperature of $80^{\circ} \mathrm{C}$ for 1 hour to produce a homogenous solution. It is then aged for 24 hours before the spincoating was done. Quartz substrates were cleaned using acetone, methanol, and deionized water in ultrasonic for 10 minutes, respectively. The solutions were dropped onto the spinning substrates with a rotation speed of $3000 \mathrm{rpm}$ for $30 \mathrm{~s}$. The films were then dried at different temperature $\left(100^{\circ} \mathrm{C}, 150^{\circ} \mathrm{C}, 200^{\circ} \mathrm{C}, 250^{\circ} \mathrm{C}\right.$, and $300^{\circ} \mathrm{C}$ ) for 10 minutes in furnace to evaporate the solvents and remove organic residuals, followed by annealing in air at $500^{\circ} \mathrm{C}$ for $1 \mathrm{~h}$. This process of coating-drying-annealing was repeated for four times until the desired thickness of the films was obtained.

The thickness of the $\mathrm{ZnO}$ nanostructures was measured using surface profiler (model: Veeco Dektak 750). The crystalline phase of the $\mathrm{ZnO}$ nanostructures was determined by X-Ray diffractometer (XRD; model: Rigaku Ultima). The surface morphology of the films were checked using field emission scanning electron microscopy (FE-SEM; model: JEOL JSM-7600F) with accelerating voltage of $5 \mathrm{kV}$. For optical characteristics, photoluminescence (PL) spectrometer (model: Horiba Jabin Yvon) using the $325 \mathrm{~nm}$ He-Cd laser as the excitation source to measure the photoluminescence spectra, and UV-Vis/NIR spectrophotometer (model: JASCO V-670) to characterize the optical transmittance spectra. Meanwhile for electrical measurements, gold was firstly sputtered on the films with a thickness of about $60 \mathrm{~nm}$ as the metal contact. 2-point probe (model: Advantest 6234) was used for the $I-V$ measurement.

\section{Results and Discussion}

3.1. Physical Properties. We first present the XRD patterns of the $\mathrm{ZnO}$ nanoparticles films dried at temperature of $100^{\circ} \mathrm{C}$ to $300^{\circ} \mathrm{C}$ in Figure 1. The XRD patterns clearly show that all films are in good agreement with standard $\mathrm{ZnO}$ diffraction pattern (JCPDS no 36-1451). It is observed that diffraction peaks $2 \theta$ of $31.95^{\circ}, 34.6^{\circ}$, and $36.35^{\circ}$ which correspond to $\left(\begin{array}{lll}1 & 0 & 0\end{array}\right),\left(\begin{array}{lll}0 & 0 & 2\end{array}\right)$, and $\left(\begin{array}{lll}1 & 0 & 1\end{array}\right)$ crystalline structure appeared at all films, and for the case of film dried at $100^{\circ} \mathrm{C}$, all the intensities are nearly the same. When the drying temperature was increased to $150^{\circ} \mathrm{C}$, the $\left(\begin{array}{ll}0 & 0\end{array}\right)$ intensity increases while the (lllll $\left.\begin{array}{lll}0 & 0\end{array}\right)$ and ( $\left(\begin{array}{lll}1 & 0 & 1\end{array}\right)$ intensities decrease. The $\left(\begin{array}{lll}0 & 0 & 2\end{array}\right)$ peak becomes dominant and reaches the maximum intensity for

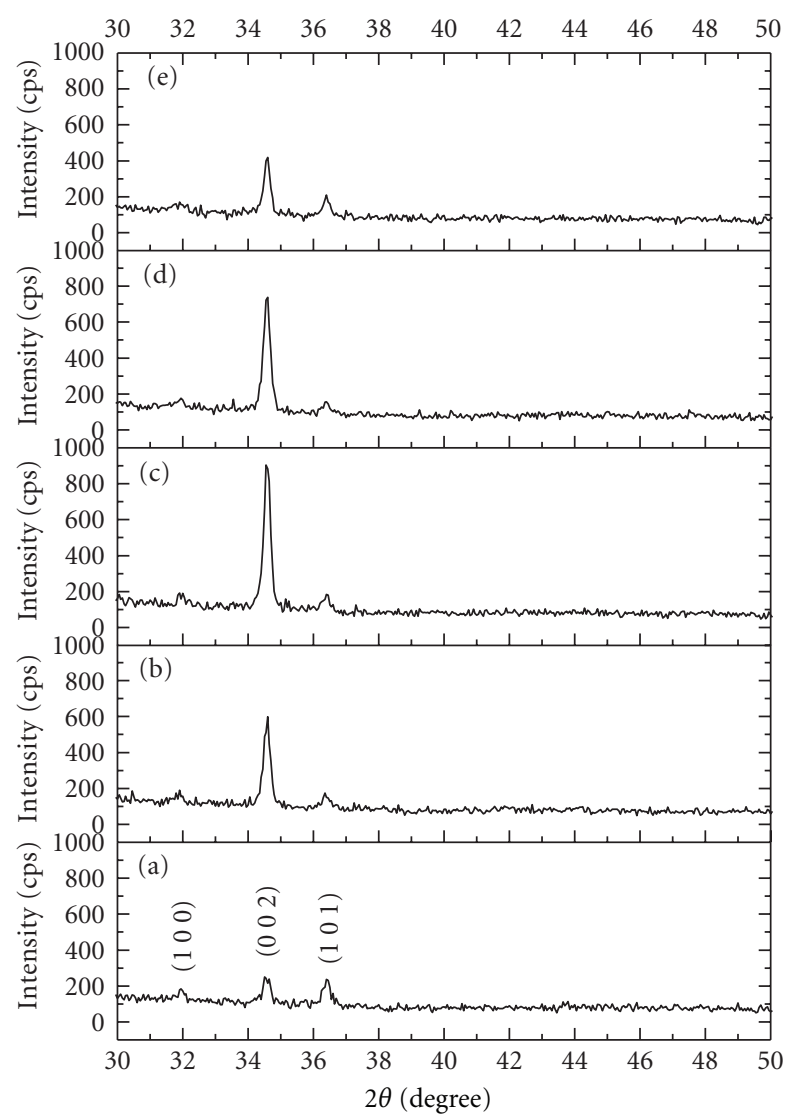

FIGURE 1: XRD patterns of the $\mathrm{ZnO}$ thin films at drying temperature of (a) $100^{\circ} \mathrm{C}$, (b) $150^{\circ} \mathrm{C}$, (c) $200^{\circ} \mathrm{C}$, (d) $250^{\circ} \mathrm{C}$, and (e) $300^{\circ} \mathrm{C}$.

film dried at $200^{\circ} \mathrm{C}$. When the temperature was increased to more than $200^{\circ} \mathrm{C}$, the intensity of the $\left(\begin{array}{lll}0 & 0 & 2\end{array}\right)$ peak started to decrease until drying temperature reached $300^{\circ} \mathrm{C}$. According to $\mathrm{Xu}$ et al., the c-axis growth of sol-gel $\mathrm{ZnO}$ films is originated from intrinsic and extrinsic factors [15]. For the intrinsic factor, $\left(\begin{array}{lll}0 & 0 & 2\end{array}\right)$ orientation is thermodynamically favourable growth direction due to its minimum surface free energy [16]. The conditions during the thin films preparations become the extrinsic factor of the c-axis orientation, which for the case of sol-gel method is highly dependent on the type of stabilizer used in the solution preparation. For our case, it is a combination of intrinsic and extrinsic factors, and also with the help of self-template of the layerby-layer process. The growth mechanism is as follows. The first layer was spin coated onto substrate and was randomly oriented. When the layer is dried, the stabilizer and solution vapoured, and this was followed by annealing which makes the film crystallized at $\left(\begin{array}{lll}0 & 0 & 2\end{array}\right)$ due to the minimum surface energy. Then when the second layer was spin coated, the first layer becomes a template to the next layer which helps the orientation to become more c-axis. With sufficient number of layers, the $\left(\begin{array}{lll}0 & 0 & 2\end{array}\right)$ orientation becomes most dominant compared to the other weak peaks.

Contemplating from the phenomenon, we deduce that the temperature during the drying process affects the crystallization of the $\mathrm{ZnO}$ as follows. The boiling temperature for 


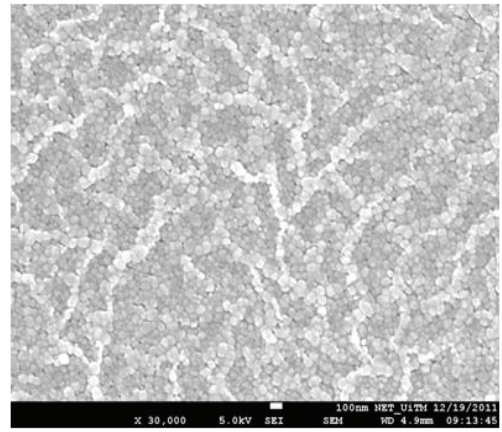

(a)

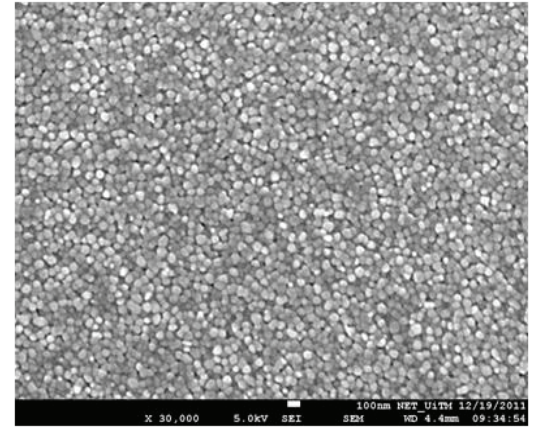

(b)

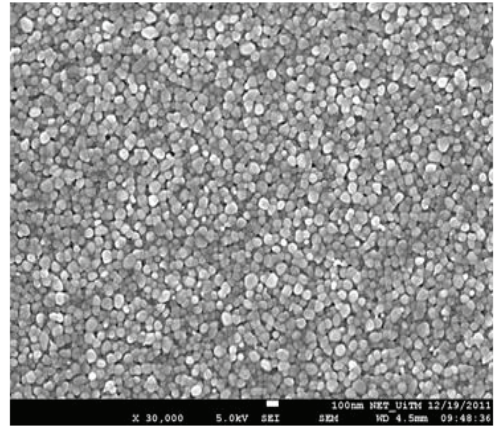

(c)

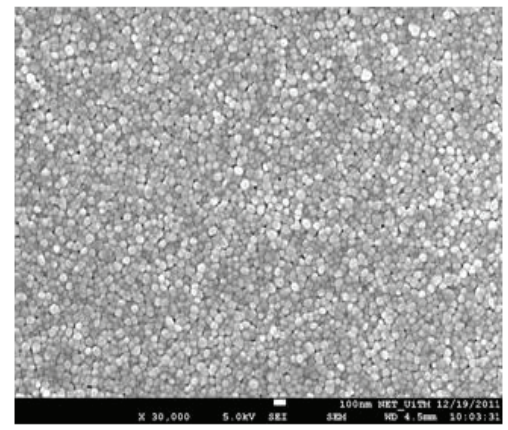

(d)

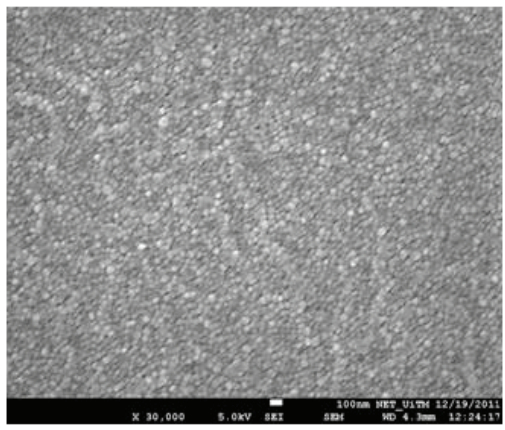

(e)

Figure 2: FE-SEM micrographs of the sol-gel layer-by-layer $\mathrm{ZnO}$ thin films dried at (a) $100^{\circ} \mathrm{C}$, (b) $150^{\circ} \mathrm{C}$, (c) $200^{\circ} \mathrm{C}$, (d) $250^{\circ} \mathrm{C}$, and (e) $300^{\circ} \mathrm{C}$.

MEA is about $170^{\circ} \mathrm{C}$, so a minimum temperature of $170^{\circ} \mathrm{C}$ is required to vapour the stabilizer from the thin films during the drying process. If the temperature is lower than that, the vaporization of the solvent and stabilizer and also thermal decomposition of the zinc acetate are not complete during the drying process. This causes abrupt vaporization of the solvent during the annealing process, which will affect the crystallization of the $\mathrm{ZnO}$ [17]. However when the drying temperature is increased to above $240^{\circ} \mathrm{C}$, the temperature is too high which also causes the solvent to vapour abruptly during the drying process.

The grain size of the $\mathrm{ZnO}$ can be calculated from the XRD pattern, using Scherer's formula [18] as depicted in (1) below:

$$
D=\frac{0.9 \lambda}{\beta \cos \theta},
$$

where $D$ is the mean size of the $\mathrm{ZnO}$ particles, $\lambda$ is the $\mathrm{X}$-ray wavelength, $\beta$ is the full width of half maximum of $\left(\begin{array}{lll}0 & 0 & 2\end{array}\right)$ peak for $\mathrm{ZnO}$, and $\theta$ is the maximum angle of the $\left(\begin{array}{lll}0 & 0 & 2\end{array}\right)$ peak in radians. The calculated grain sizes are tabulated in Table 1. It is observed that the grain size increased from $37.1 \mathrm{~nm}$ to $41.6 \mathrm{~nm}$ when the temperature increased to $200^{\circ} \mathrm{C}$. For films dried at temperature above $250^{\circ} \mathrm{C}$, the grain size decreased from $36.3 \mathrm{~nm}$ to $36.0 \mathrm{~nm}$. According to Kim et al. [19], when the film is dried at temperature of below $250^{\circ} \mathrm{C}$, the particle size may increased due to nondisturbance of the preferential growth during the annealing process. For the films dried
TABle 1: Average particles size for $\mathrm{ZnO}$ nanoparticles at different drying temperature.

\begin{tabular}{lcc}
\hline $\begin{array}{l}\text { Drying temperature } \\
\left({ }^{\circ} \mathrm{C}\right)\end{array}$ & $\begin{array}{c}\text { Average grain size } \\
(\mathrm{nm})\end{array}$ & $\begin{array}{c}\text { Film thickness } \\
(\mathrm{nm})\end{array}$ \\
\hline 100 & 37.1 & 109.5 \\
150 & 37.9 & 93.9 \\
200 & 41.6 & 90.5 \\
250 & 36.3 & 104.8 \\
300 & 36.0 & 110.2 \\
\hline
\end{tabular}

above $250^{\circ} \mathrm{C}$, the abrupt vaporization of the solvents disturbed the crystal growth, thus decreases the particle size.

Figure 2 shows the FE-SEM micrographs of the $\mathrm{ZnO}$ films dried at different temperatures. The micrographs show that the $\mathrm{ZnO}$ nanoparticles films are porous, which is a common phenomenon for sol-gel $\mathrm{ZnO}$ thin films [20, 21]. The grains become more uniform and denser as the drying temperature increases from 100 to $200^{\circ} \mathrm{C}$.

3.2. Optical Properties. Room temperature PL spectra were measured in the wavelength range of 350 to $700 \mathrm{~nm}$. Figure 3 shows the PL spectra for the $\mathrm{ZnO}$ nanoparticles films dried at different temperature. From the PL spectra, three peaks were detected, UV emission peak centered at $380 \mathrm{~nm}$, visible peak centered at about $440 \mathrm{~nm}$, and another peak centered at $580 \mathrm{~nm}$. The UV emission is attributed to the free-exciton emission $[22,23]$. It is observed that the intensity of the UV 


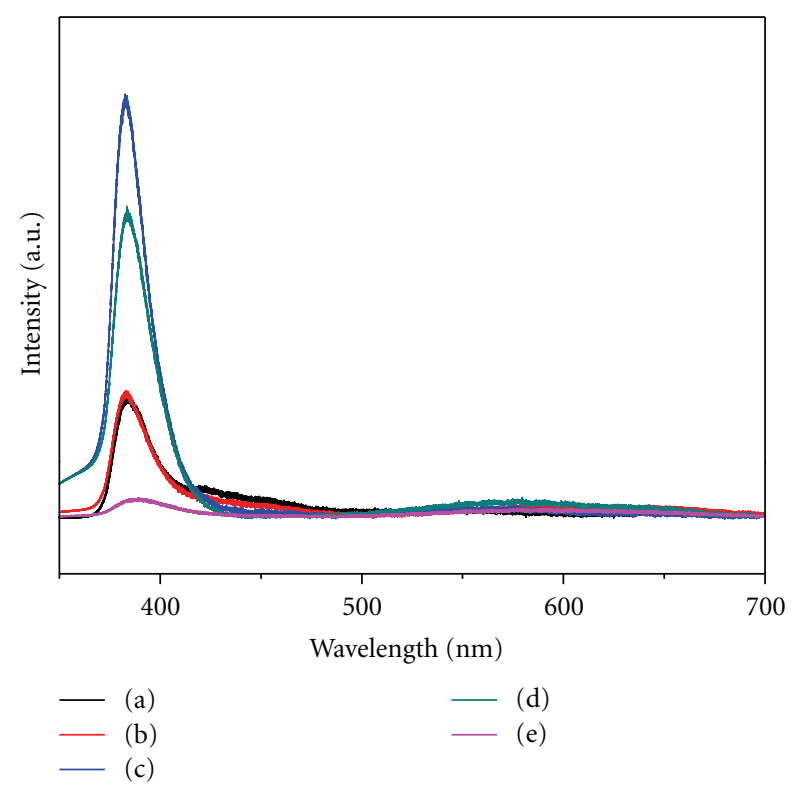

Figure 3: Photoluminescence spectra of the $\mathrm{ZnO}$ nanoparticles dried at (a) $100^{\circ} \mathrm{C}$, (b) $150^{\circ} \mathrm{C}$, (c) $200^{\circ} \mathrm{C}$, (d) $250^{\circ} \mathrm{C}$, and (e) $300^{\circ} \mathrm{C}$.

emission gradually increased with the drying temperature. However, when the temperature was increased above $200^{\circ} \mathrm{C}$, the intensity decreased. It is known that the UV emission is related to the crystalline structure of the $\mathrm{ZnO}$ films as described by $\mathrm{Xu}$ et al. [15] and Chatterjee et al. [24]. When the crystalline quality is improved, the density of the free exciton becomes higher, which is correlated to the UV emission. It is also found that the UV emission is also affected by the grain size of the $\mathrm{ZnO}[24]$ which is in great agreement with the XRD result.

It is known that visible emission of $\mathrm{PL}$ in $\mathrm{ZnO}$ is attributed to crystalline defect such as $\mathrm{Zn}$ interstitial and oxygen vacancy. According to Schmit-Mende, the intrinsic defects are known as $\mathrm{Zn}_{i}^{\star \bullet}, \mathrm{Zn}_{i}^{\star}, \mathrm{Zn}_{i}^{X}, V_{\mathrm{O}}^{\bullet}, V_{\mathrm{O}}^{\star}$, and $V_{\mathrm{O}}$ which are the donor defects; $V_{\mathrm{Zn}}^{\prime \prime}$ and $V_{\mathrm{Zn}}^{\prime}$ which are the acceptor defects [25]. Until now the dominant defect of the visible emission is still a controversy, but either $V_{\mathrm{O}}$ or $\mathrm{Zn}_{i}$ is generally considered as the primary defect responsible for this emission [26]. $\mathrm{ZnO}$ films dried at $100^{\circ} \mathrm{C}$ and $150^{\circ} \mathrm{C}$ show a shoulder peak of blue emission centred at $440 \mathrm{~nm}$ as depicted in Figure 4. The blue emission is originated from the electron transition from the shallow donor level of oxygen vacancies to the valence band [27]. However, for the films dried at above $250^{\circ} \mathrm{C}$, visible emission is red shifted to broad emission centred at about $570 \mathrm{~nm}$ as shown in Figure 5. When the temperature was further increased to $300^{\circ} \mathrm{C}$, the intensity becomes quenched and more red shifted. According to O'Brien et al. the yellow-orange emission is attributed to the interstitial oxygen ions [28].

From the PL spectra, band gap of the $\mathrm{ZnO}$ can be calculated using Planck's constant as in (2):

$$
E=\frac{h c}{\lambda},
$$

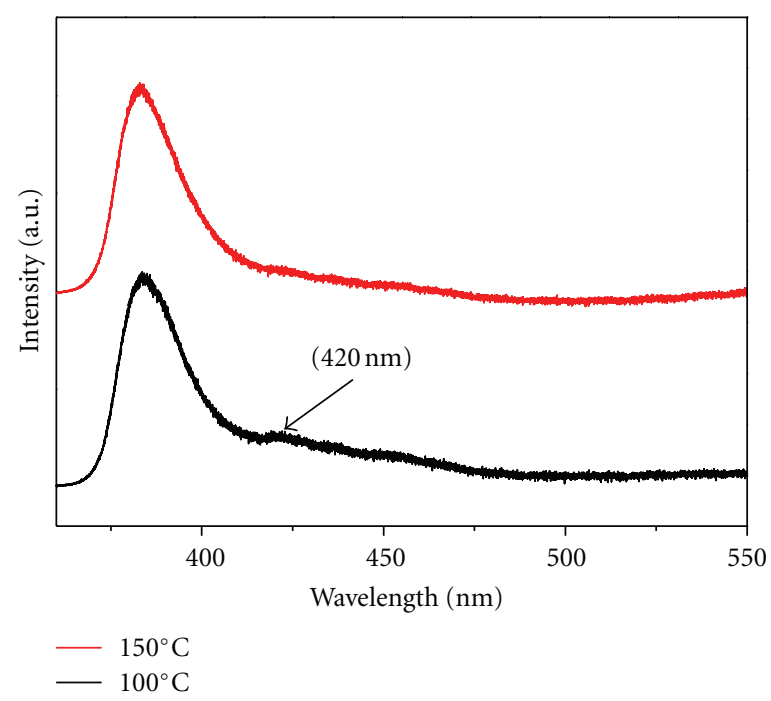

FIGURE 4: Comparison of PL spectra of $\mathrm{ZnO}$ nanoparticles dried at $100^{\circ} \mathrm{C}$ and $150^{\circ} \mathrm{C}$.

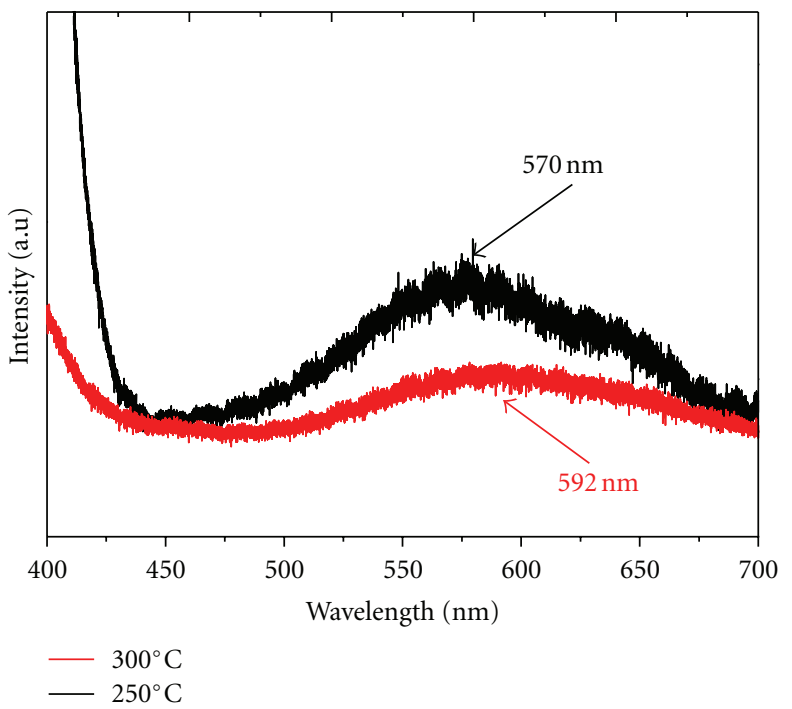

FIgURE 5: Comparison of PL spectra of $\mathrm{ZnO}$ nanoparticles dried at $250^{\circ} \mathrm{C}$ and $300^{\circ} \mathrm{C}$.

where $E$ is the the band gap, $h$ is the Planck's constant with a value of $4.135667 \times 10^{-15} \mathrm{eVs}, c$ is the velocity of light of $3.0 \times 10^{8}$, and $\lambda$ is the wavelength of the spectra in the UV emission. Optical band gaps of the $\mathrm{ZnO}$ nanoparticles are shown in Table 2. It was found that the band gap increases with the drying temperature and maximized at temperature of $200^{\circ} \mathrm{C}$; when the temperature is increased to more than $250^{\circ} \mathrm{C}$, the optical band gap decreases with lowest value given by films dried at $300^{\circ} \mathrm{C}$. It is found that the optical band gap is influenced by the crystalline quality of the films.

Transmittance spectra were measured within the wavelength of 300 to $700 \mathrm{~nm}$ and are shown in Figure 6. The sharp ultraviolet absorption edges at the wavelength of about $370 \mathrm{~nm}$. The average transmittance spectra in the visible emission increased with the drying temperature but 
TABLE 2: Optical band gap and average transmittance of the $\mathrm{ZnO}$ nanoparticles at different drying temperatures.

\begin{tabular}{|c|c|c|c|c|c|}
\hline Drying temperature & $100^{\circ} \mathrm{C}$ & $150^{\circ} \mathrm{C}$ & $200^{\circ} \mathrm{C}$ & $250^{\circ} \mathrm{C}$ & $300^{\circ} \mathrm{C}$ \\
\hline Optical band gap (eV) & 3.23 & 3.24 & 3.25 & 3.23 & 3.20 \\
\hline Average transmittance (\%) & 85.32 & 86.15 & 86.84 & 86.40 & 85.52 \\
\hline
\end{tabular}
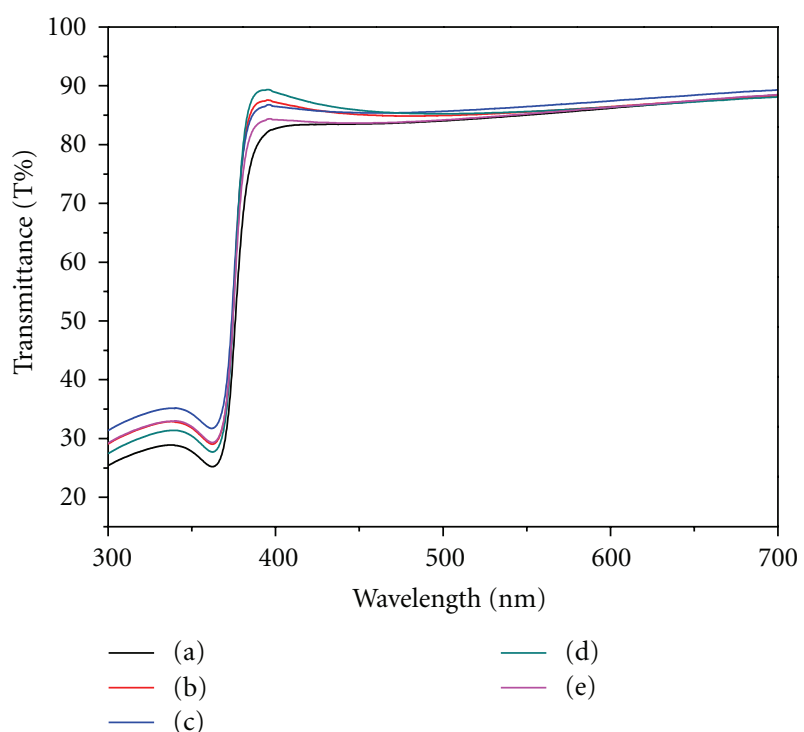

Figure 6: Transmittance spectra of the $\mathrm{ZnO}$ nanoparticles dried at (a) $100^{\circ} \mathrm{C}$, (b) $150^{\circ} \mathrm{C}$, (c) $200^{\circ} \mathrm{C}$, (d) $250^{\circ} \mathrm{C}$, and (e) $300^{\circ} \mathrm{C}$.

decreased when the temperature reached $250^{\circ} \mathrm{C}$ and above as shown in Table 2. Contemplating from the phenomena, we deduce that the transparency of the films is dependent on the crystalline quality. The transmittance is lower in lower c-axis sample because much light is dispersed in the grain boundary [19]. Highest transparency is given by film dried at $200^{\circ} \mathrm{C}$ which is $86.84 \%$, which also shows the highest caxis orientation.

3.3. Electrical Properties. $I-V$ measurements were done in room temperature with applied voltage in the range of $-10 \mathrm{~V}$ to $10 \mathrm{~V}$. Linear $I-V$ curves are shown in Figure 7(a), indicating that all of the $\mathrm{ZnO}$ nanoparticles show ohmic behaviour with the gold metal contact. It is observed that the current increased with the drying temperature, with the highest current given by film dried at $300^{\circ} \mathrm{C}$. From the $I-V$ graph, resistivity was calculated and shown in Figure 7(b). As expected from the current value, the resistivity is inversely proportionate to the drying temperature. For the case of films annealed at temperature lower than $200^{\circ} \mathrm{C}$, the resistivity decrease with the increasing temperature might be due to the improvement of the crystalline quality and also the increase of grain size [29]. When the drying temperature was further increased to $250^{\circ} \mathrm{C}$, the resistivity keeps on decreasing even though the crystalline structure was decreased. The cause to this phenomenon is still under our investigation.

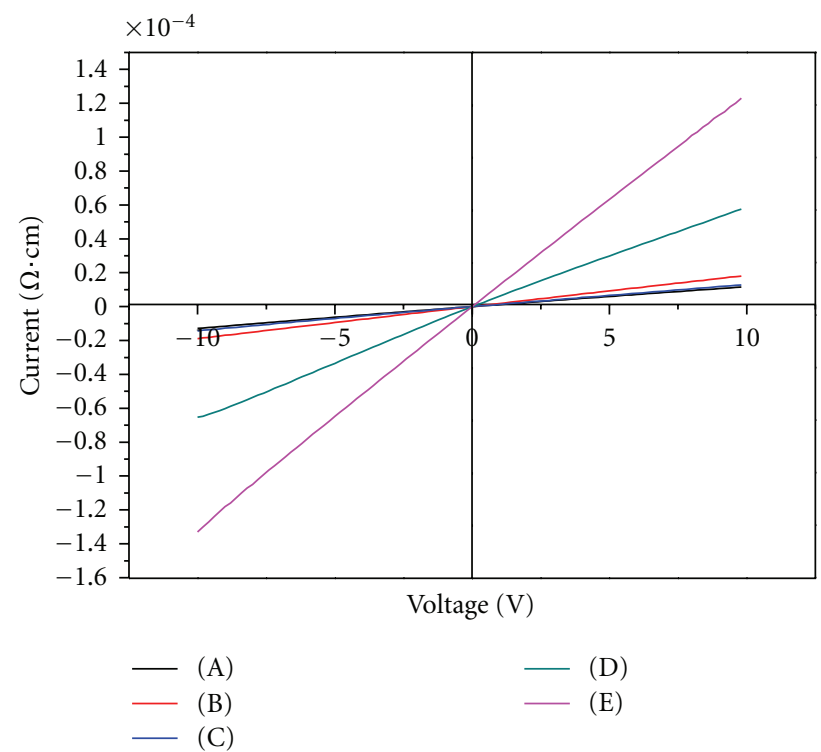

(a)

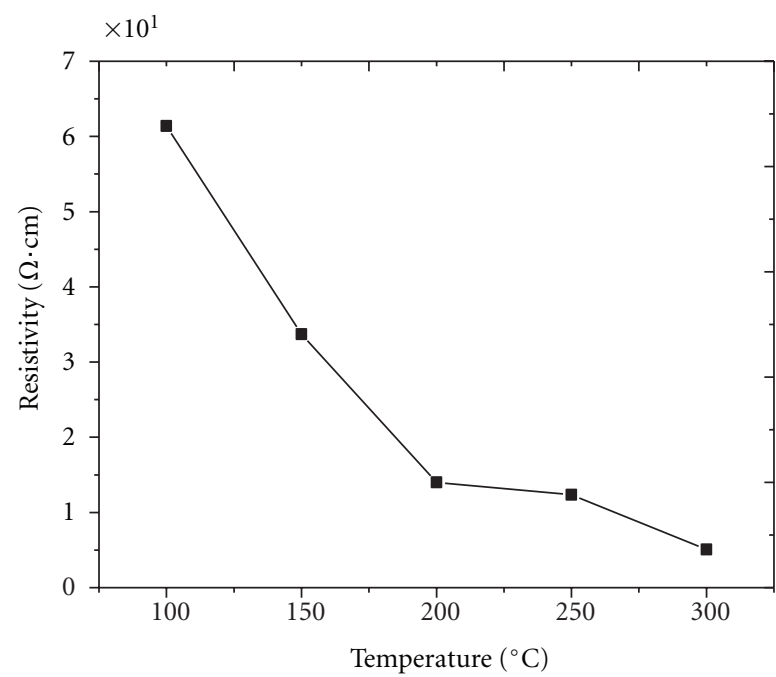

(b)

Figure 7: (a) $I-V$ measurements of the sol-gel layer-by-layer $\mathrm{ZnO}$ thin films dried at (A) $100^{\circ} \mathrm{C}$, (B) $150^{\circ} \mathrm{C}$, (C) $200^{\circ} \mathrm{C}$, (D) $250^{\circ} \mathrm{C}$, and (E) $300^{\circ} \mathrm{C}$ and (b) resistivity of the $\mathrm{ZnO}$ nanoparticles at different drying temperature.

\section{Conclusion}

$\mathrm{ZnO}$ nanoparticles films were deposited using sol-gel spin coating technique on quartz substrates to be used as seeded catalyst. It was found that the crystalline structure, morphology, optical, and electrical properties were highly 
dependent on the drying temperature. We conclude that the optimum drying temperature for the $\mathrm{ZnO}$ films to be used as seeded catalyst was at $200^{\circ} \mathrm{C}$, which showed highest $(0$ 0 2) diffraction peak due to complete vaporization of the solvent and decomposition of the zinc acetate. Morphologies were also affected by the drying temperature, with the grain size increasing with the drying temperature until $200^{\circ} \mathrm{C}$. $\mathrm{PL}$ spectra indicated that the film dried at $200^{\circ} \mathrm{C}$ exhibits the highest UV emission peak which is due to the highest crystalline structure. Resistivity of the films decreased with the temperature due to the improvement of the crystalline quality up to $200^{\circ} \mathrm{C}$.

\section{Acknowledgments}

The authors would like to acknowledge Faculty of Mechanical Engineering, UiTM for their XRD instrument. Also they would like to thank Ministry of Higher Education, Malaysia, and Research Management Institute (RMI), Universiti Teknologi MARA, for funding this research.

\section{References}

[1] C. Wongchoosuk, K. Subannajui, A. Menzel et al., "Controlled synthesis of $\mathrm{ZnO}$ nanostructures: the role of source and substrate temperatures," The Journal of Physical Chemistry C, vol. 115, no. 3, pp. 757-761, 2011.

[2] K. S. Kim and H. W. Kim, "Synthesis of $\mathrm{ZnO}$ nanorod on bare Si substrate using metal organic chemical vapor deposition," Physica B, vol. 328, no. 3-4, pp. 368-371, 2003.

[3] X. Liu, Z. Jin, S. Bu, J. Zhao, and K. Yu, "Preparation of ZnO nanorods and special lath-like crystals by aqueous chemical growth (ACG) method," Materials Science and Engineering B, vol. 129, no. 1-3, pp. 139-143, 2006.

[4] T. Dedova, M. Krunks, M. Grossberg, O. Volobujeva, and I. Oja Acik, "A novel deposition method to grow $\mathrm{ZnO}$ nanorods: spray pyrolysis," Superlattices and Microstructures, vol. 42, no. 1-6, pp. 444-450, 2007.

[5] S. Y. Pung, K. L. Choy, and X. Hou, "Tip-growth mode and base-growth mode of $\mathrm{Au}$-catalyzed zinc oxide nanowires using chemical vapor deposition technique," Journal of Crystal Growth, vol. 312, no. 14, pp. 2049-2055, 2010.

[6] C. Andreazza-Vignolle, P. Andreazza, and D. Zhao, "Catalyst effect on $\mathrm{ZnO}$ nanostructure shape," Superlattices and Microstructures, vol. 39, no. 1-4, pp. 340-347, 2006.

[7] S. C. Lyu, Y. Zhang, H. Ruh et al., "Low temperature growth and photoluminescence of well-aligned zinc oxide nanowires," Chemical Physics Letters, vol. 363, no. 1-2, pp. 134-138, 2002.

[8] S. N. Cha, B. G. Song, J. E. Jang et al., "Controlled growth of vertically aligned $\mathrm{ZnO}$ nanowires with different crystal orientation of the ZnO seed layer," Nanotechnology, vol. 19, no. 23, Article ID 235601, 2008.

[9] C. Li, G. Fang, J. Li, L. Ai, B. Dong, and X. Zhao, "Effect of seed layer on structural properties of $\mathrm{ZnO}$ nanorod arrays grown by vapor-phase transport," The Journal of Physical Chemistry C, vol. 112, no. 4, pp. 990-995, 2008.

[10] M. Caglar, S. Ilican, Y. Caglar, and F. Yakuphanoglu, "Electrical conductivity and optical properties of $\mathrm{ZnO}$ nanostructured thin film," Applied Surface Science, vol. 255, no. 8, pp. 44914496, 2009.

[11] Y. Natsume and H. Sakata, "Zinc oxide films prepared by solgel spin-coating," Thin Solid Films, vol. 372, no. 1, pp. 30-36, 2000 .
[12] Y. S. Ho and K. Y. Lee, "Fabrication of highly oriented (002) ZnO film on glass by sol-gel method," Thin Solid Films, vol. 519, no. 4, pp. 1431-1434, 2010.

[13] M. Saleem, L. Fang, H. Ruan et al., "Effect of zinc acetate concentration on the structural and optical properties of $\mathrm{ZnO}$ thin films deposited by Sol-Gel method," International Journal of Physical Sciences, vol. 7, no. 23, pp. 2971-2979, 2012.

[14] J. Sengupta, R. K. Sahoo, K. K. Bardhan, and C. D. Mukherjee, "Influence of annealing temperature on the structural, topographical and optical properties of sol-gel derived $\mathrm{ZnO}$ thin films," Materials Letters, vol. 65, no. 17-18, pp. 2572-2574, 2011.

[15] L. Xu, X. Li, Y. Chen, and F. Xu, "Structural and optical properties of $\mathrm{ZnO}$ thin films prepared by sol-gel method with different thickness," Applied Surface Science, vol. 257, no. 9, pp. 4031-4037, 2011.

[16] N. Fujimura, T. Nishihara, S. Goto, J. Xu, and T. Ito, "Control of preferred orientation for $\mathrm{ZnOx}$ films: control of selftexture," Journal of Crystal Growth, vol. 130, no. 1-2, pp. 269279, 1993.

[17] A. Pakdel and F. E. Ghodsi, "Influence of drying conditions on the optical and structural properties of sol-gel-derived $\mathrm{ZnO}$ nanocrystalline films," Pramana, vol. 76, no. 6, pp. 973-983, 2011.

[18] A. K. Singh, V. Viswanath, and V. C. Janu, "Synthesis, effect of capping agents, structural, optical and photoluminescence properties of $\mathrm{ZnO}$ nanoparticles," Journal of Luminescence, vol. 129, no. 8, pp. 874-878, 2009.

[19] Y. S. Kim, W. P. Tai, and S. J. Shu, "Effect of preheating temperature on structural and optical properties of $\mathrm{ZnO}$ thin films by sol-gel process," Thin Solid Films, vol. 491, no. 1-2, pp. 153160, 2005.

[20] A. R. Bari, M. D. Shinde, V. Deo, and L. A. Patil, "Effect of solvents on the particle morphology of nanostructurcd $\mathrm{ZnO}$," Indian Journal of Pure and Applied Physics, vol. 47, no. 1, pp. 24-27, 2009.

[21] N. J. Kim, S. L. Choi, H. J. Lee, and K. J. Kim, "Nanostructures and luminescence properties of porous $\mathrm{ZnO}$ thin films prepared by sol-gel process," Current Applied Physics, vol. 9, no. 3, pp. 643-646, 2009.

[22] K. F. Lin, H. M. Cheng, H. C. Hsu, L. J. Lin, and W. F. Hsieh, "Band gap variation of size-controlled $\mathrm{ZnO}$ quantum dots synthesized by sol-gel method," Chemical Physics Letters, vol. 409, no. 4-6, pp. 208-211, 2005.

[23] Q. Li, J. Bian, J. Sun et al., "Controllable growth of well-aligned $\mathrm{ZnO}$ nanorod arrays by low-temperature wet chemical bath deposition method," Applied Surface Science, vol. 256, no. 6, pp. 1698-1702, 2010.

[24] A. Chatterjee, C. H. Shen, A. Ganguly et al., "Strong roomtemperature UV emission of nanocrystalline $\mathrm{ZnO}$ films derived from a polymeric solution," Chemical Physics Letters, vol. 391, no. 4-6, pp. 278-282, 2004.

[25] L. Schmidt-Mende and J. L. MacManus-Driscoll, " $\mathrm{ZnO}-$ nanostructures, defects, and devices," Materials Today, vol. 10, no. 5, pp. 40-48, 2007.

[26] P. Sagar, P. K. Shishodia, R. M. Mehra, H. Okada, A. Wakahara, and A. Yoshida, "Photoluminescence and absorption in solgel-derived ZnO films," Journal of Luminescence, vol. 126, no. 2, pp. 800-806, 2007.

[27] D. H. Zhang, Z. Y. Xue, and Q. P. Wang, "The mechanisms of blue emission from $\mathrm{ZnO}$ films deposited on glass substrate by r.f. magnetron sputtering," Journal of Physics D, vol. 35, no. 21, pp. 2837-2840, 2002. 
[28] S. O’Brien, L. H. K. Koh, and G. M. Crean, “ZnO thin films prepared by a single step sol-gel process," Thin Solid Films, vol. 516, no. 7, pp. 1391-1395, 2008.

[29] J. H. Lee, K. H. Ko, and B. O. Park, "Electrical and optical properties of $\mathrm{ZnO}$ transparent conducting films by the sol-gel method," Journal of Crystal Growth, vol. 247, no. 1-2, pp. 119125, 2003. 

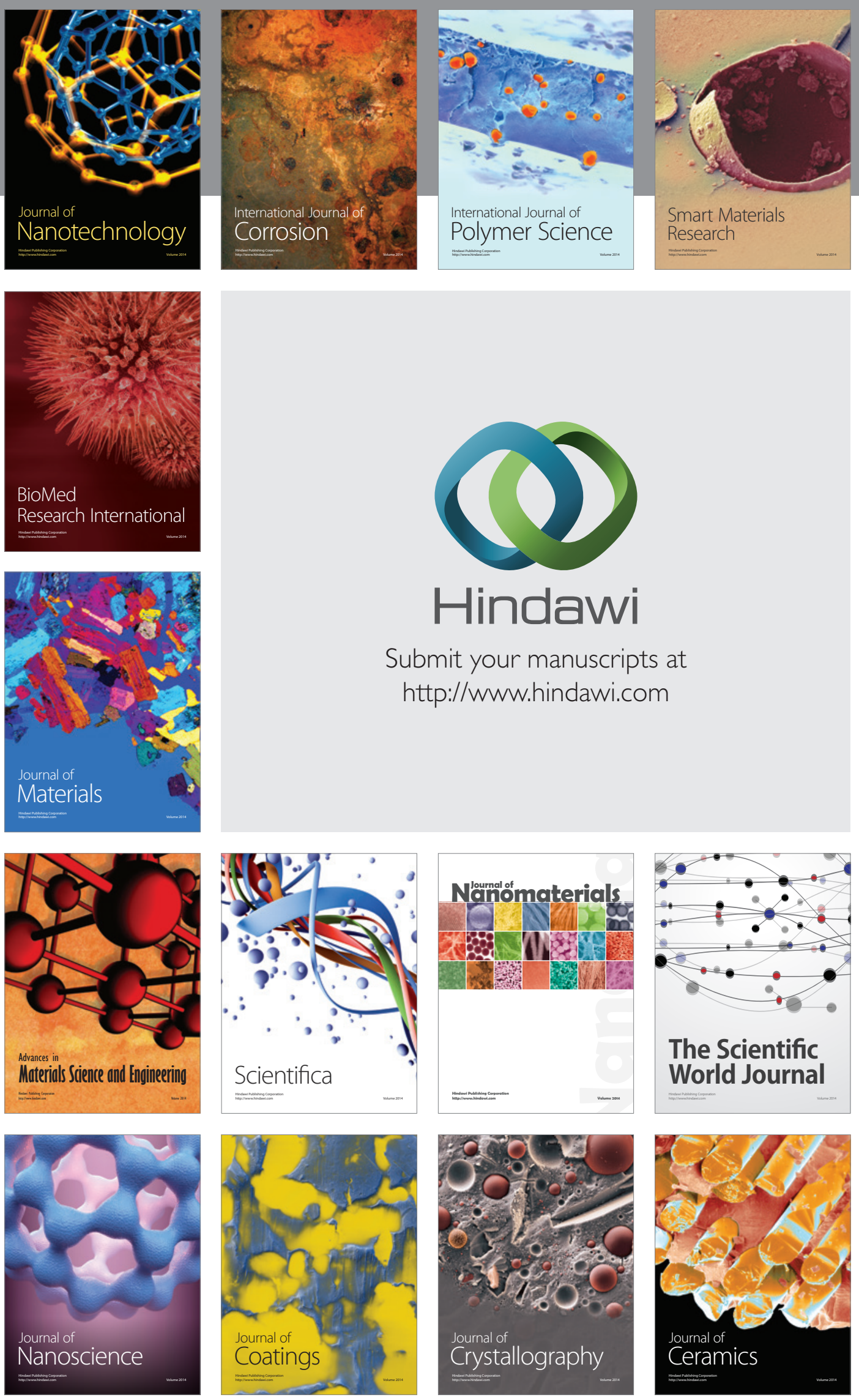

The Scientific World Journal

Submit your manuscripts at

http://www.hindawi.com

\section{World Journal}

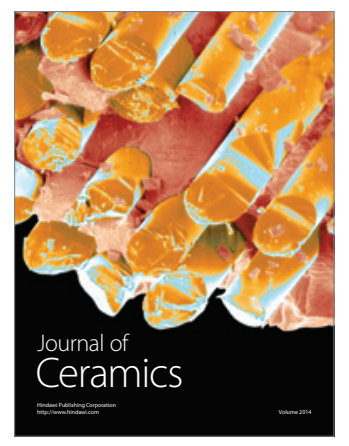

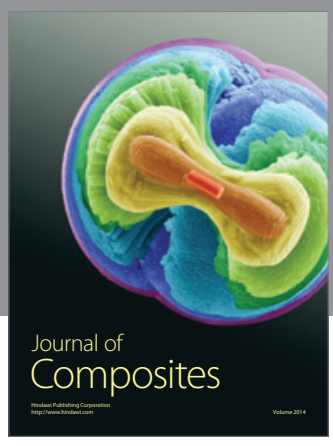
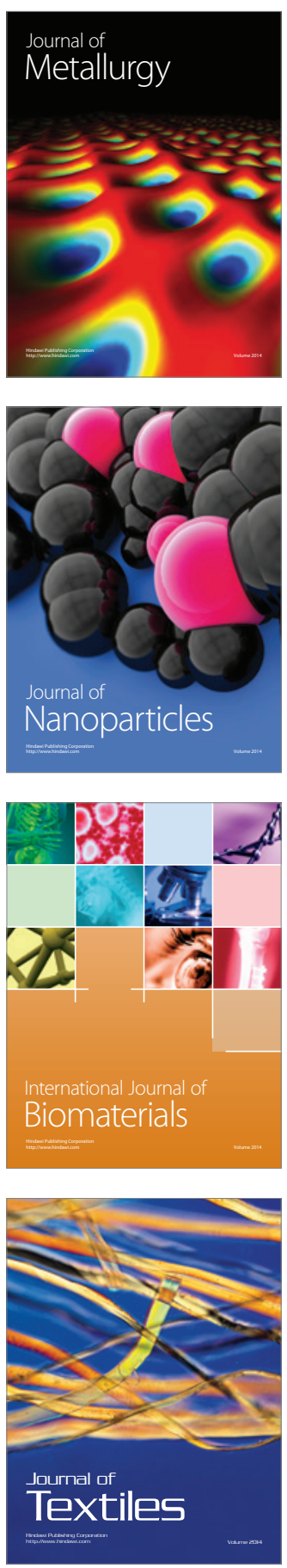